\title{
WIRELESS ENERGY SUPPLY TO PUBLIC TRANSPORT UNITS WITH HYBRID DRIVE - TRENDS AND CHALLENGES
}

\author{
Igors Graurs ${ }^{1}$, Aleksandrs Vizulis ${ }^{2}$, Aivars Rubenis ${ }^{3}$, Aigars Laizāns ${ }^{4}$ \\ ${ }^{1}$ LEO Research Centre, Riga, Latvia \\ Transport and Telecommunication Institute, Riga, Latvia \\ E-mail: Graurs.I@tsi.lv \\ ${ }^{2}$ LEO Research Centre, Riga, Latvia \\ Kavitus, SIA, Jelgava, Latvia \\ E-mail:a_vizulis@yahoo.com \\ ${ }^{3}$ LEO Research Centre, Riga, Latvia, \\ RS Factor, Riga, Latvia \\ E-mail: aivars.rubenis@ivorygroup.eu \\ ${ }^{4}$ LEO Research Centre, Riga, Latvia, \\ Latvia University of Agriculture, Jelgava, Latvia \\ E-mail:aigars.laizans@llu.lv
}

\begin{abstract}
This paper describes the initial findings of research project "The Possibilities of Increasing Efficiency of City Bus Hybrid Propulsion Systems by Including Wireless Battery Charging” carried out by „LEO Research Centre” (Competency Centre for Latvian Electrical and Optical Manufacturing Industry).

The project is aimed at developing wireless charging and optimising electric bus propulsion system for modern urban transportation applications. The project runs from the beginning of the 2013 until the end of 2015 and focuses on the sub-theme "Energy and Sustainable Transport".
\end{abstract}

Keywords: public transport; transport units with hybrid drive; conductive energy transfer; wireless energy transfer

\section{Introduction}

Currently the world's growing public focus is on the development of environmentally friendly technologies, including applications in the transport sector. At the same time, public transport, especially buses, is the largest contributor to air pollution in cities.

To stimulate transition from fossil fuels to renewable energy-using engines, especially - electric transport, the European Commission issued in 2011 the White Paper "Roadmap to a Single European Transport Area - towards a Competitive and Resource Efficient Transport System", which encompasses "... by 2030 to reduce by half the usage of 'traditional fuel' cars used for urban transportation; by 2050 to cease stage-by-stage its usage in cities; by 2030 to achieve virtually zero $\mathrm{CO}_{2}$ emissions in major population centres from city logistics" [1].

Currently well over $50 \%$ of all public transportation trips are completed by bus, but, unfortunately, usage of electric buses in the world has been rather symbolic. The main reason for this is electric bus price, which is caused by large volume expensive batteries and currently exceeds any economic efficiency criteria; therefore, battery electric buses have been presented only as separate pilot projects: USA (California), United Kingdom (Nottingham, Coventry), Sweden (Umea) and China; however, in the last years the number of similar projects increased exponentially, showing great interest in the development of new technologies in the city transportation systems.

From the perspective of overall economical reasoning hybrid buses are already economically viable, yet recovered amount of energy so far is very limited - the hybrid electric vehicle (HEV) energy recuperation and replacement technology allows us to recover up to $15 \%$ of the energy in the urban cycle, thereby the gain of $\mathrm{CO}_{2}$ emission reduction is not substantially high. The general industry problem, which 
is intended to be addressed in this project, is the following - to explore the possibilities of developing the wireless battery charging system for the bus electric drive system that would allow benefiting from opportunities, given by electricity as driving force (power, efficiency, lower costs), while avoiding substantial increase in bus and infrastructure costs.

\section{Definition of the Problem}

The research problem derives from practical application problem - how to create the most efficient zero emission bus system, which would be economically feasible to implement.

While evaluating this system, city transportation system must be seen as a whole, taking into account all possible transportation modes for compatible particular vehicle application. In case of alternatives to a city bus several options must be evaluated and compared:

a) Ordinary diesel bus;

b) Minibus;

c) LPG/LNG bus;

d) Trolley bus with overhead lines;

e) Electric bus;

f) Hybrid drive bus.

These are just the main groups - in practice there are a lot more: Pierre Ducharme and Simon Ouellette determined six propulsion types of hybrid electric engines with additional six power train configurations [2].

This research will compare three main groups - classical ordinary diesel bus, electric bus with trolley as electrical energy supply system, and electric bus with hybrid/accumulator as energy supply system.

In general, when seeking how to minimize total costs of ownership (TCO) for environmentally clean city transport one must compare TCO for each vehicle system.

$T C O_{\text {system }}=T C O_{\text {vehicle type }}+T C O_{\text {infrastructure. }}$

Each of these parts in turn will consist of three main components: purchase price $(\mathrm{P})$, residual value (V) and cost of operation (C).

$T C O_{\text {vehicle type }}=\frac{P_{\text {vehicle }}-V_{\text {residual }}}{\text { years }}+C_{\text {service }}$ operaton.

When comparing electric busses with their counterparts, we see still quite a lot unknown values, which moreover are inter-dependable (Table 1).

Table1. Some variables for TCO estimation

\begin{tabular}{|c|c|c|c|c|c|c|c|c|}
\hline \multirow{2}{*}{$\begin{array}{l}\text { Type of } \\
\text { vehicle }\end{array}$} & \multicolumn{4}{|l|}{ Vehicle } & \multicolumn{4}{|c|}{ Infrastructure } \\
\hline & $\begin{array}{l}\text { Purchase } \\
\text { costs }\end{array}$ & Residual value & $\begin{array}{l}\text { Costs of } \\
\text { operation }\end{array}$ & $\begin{array}{l}\text { Years of } \\
\text { service }\end{array}$ & $\begin{array}{l}\text { Purchase } \\
\text { costs }\end{array}$ & $\begin{array}{l}\text { Residual } \\
\text { value }\end{array}$ & $\begin{array}{l}\text { Costs of } \\
\text { operation }\end{array}$ & $\begin{array}{l}\text { Years of } \\
\text { service }\end{array}$ \\
\hline Ordinary bus & Low & Moderate/Low & High & $\begin{array}{l}7-12[3] / \\
20+[4]\end{array}$ & \multicolumn{4}{|c|}{$\begin{array}{l}\text { Assumptions that there are no additional } \\
\text { costs, as other vehicles use the roads as well }\end{array}$} \\
\hline Trolley bus & High & Moderate/Low & Low & $12 / 20+$ & High & Low & High & $25+$ \\
\hline Electric bus & High & Unknown & Low & $\begin{array}{l}\text { Unknown } \\
\text { battery life }\end{array}$ & $\begin{array}{l}\text { Low to } \\
\text { High }\end{array}$ & Low & $\begin{array}{l}\text { None to } \\
\text { High }\end{array}$ & $\begin{array}{l}\text { Unknown } \\
\text { to } 25\end{array}$ \\
\hline
\end{tabular}

Apart from these objective variables, one must include subjective factors that in practice are included in the process of decision on vehicle system, like aesthetics of the system (some cities will pay more to avoid the ugly looking overhead lines), willingness to pay more for environmentally friendly energy, etc.

This particular project will address the problem how the on-board battery capacity affects the TCO of electric or hybrid electric bus.

The main chains of effects are presented in the Table 2. 
Table 2. Main chains of effects of on-board battery size

\begin{tabular}{|c|c|c|c|c|c|c|c|}
\hline Batteries & $\uparrow$ & Drive distance & $\uparrow$ & $\begin{array}{l}\text { Charging infrastructure } \\
\text { costs }\end{array}$ & $\downarrow$ & & \\
\hline & & & & $\begin{array}{l}\text { Alternative charging } \\
\text { infrastructure }\end{array}$ & ? & $\begin{array}{l}\text { Charging infrastructure } \\
\text { costs }\end{array}$ & $?$ \\
\hline & & & & Useful drive time & 个 & Income & $\uparrow$ \\
\hline Batteries & $\uparrow$ & Vehicle costs & $\uparrow$ & & & & \\
\hline Batteries & $\uparrow$ & Lifetime & ? & Residual value & $?$ & & \\
\hline Batteries & $\uparrow$ & Vehicle weight & $\uparrow$ & Energy consumed & $\uparrow$ & & \\
\hline & & & & Passengers on board & $\downarrow$ & Income & $\downarrow$ \\
\hline
\end{tabular}

As it's shown in the Table 2, the relationships are by no means straightforward. So, increasing battery size would increase the costs of the vehicle. Additionally it would add to its weight and it has been determined that if the 14 ton bus' mass increases per $1000 \mathrm{~kg}$, the corresponding power consumption increases by $0.03-0.04 \mathrm{kWh} / \mathrm{km}$ at constant speed, which corresponds to $3-4 \%$ of power consumption [5]. On the other hand, larger battery size would give additional driving distance, thus decreasing charging infrastructure costs for wireless charging.

Furthermore, the particular practical implementation of various alternatives available on the market can lead to opposite results, especially when looking at battery lifetime and residual values of the vehicle. Thus there is a wide area for research in optimisation of on-board battery parameters.

\section{Description of the Research}

\subsection{Background information on hybrid busses}

Hybrid bus production is the leading trend in public transportation. Major bus producers all over the world are involved in the production and tests. The most active players in this market are North American companies, which have strong cooperation with large energy producing companies and national research laboratories like EPRI, General Electric, NREL, INEEL, ISE Research. Development of hybrid busses in this region started on 1997, and currently several thousands of hybrid busses driven by internal combustion engine driven or fuel cells driven hybrid systems are operating in the market of public transportation.

Hybrid transport's economic and environmental performance improvement is determined by qualitatively different "ID" operation conditions. The diesel engine will run steady state, which is the optimal from the fuel economy and harmful emissions point of view.

Diesel with less power usage in hybrid bus, compared with a serial produced type, braking energy recuperation options, overrun time and deceleration time allow us to save up to $50 \%$ of fuel. Hybrid bus handling and comfort are ensured by drive systems and the electric driver response time to the driver's speed. Electrical system significantly increases the mechanical and hydro-mechanical system speed. Traction equipment noisiness is reduced due to the elimination of mechanical connection between the engine and the wheels. The traction drive control electronics will allow fulfilling the control and service functions that are not available in ordinary vehicle.

USA and Canada are between the largest hybrid busses, at most part diesel electric, consumers. Research projects of public transportation with LPG or fuel cells elements are not topical there because of questionable commercialization and business development possibilities. As an example one could mention the case of New Your city, which denied the idea of 200 LPG (LNG) driven busses purchases, buying the same amount of hybrid busses. Finally the government decided to switch to hybrid transportation as main public transportation principle, stressing on the facts, that diesel electric busses with very similar ecologic impact on environment, are more economically viable, they have also substantial strengths in comfort and daily use and management, they do not require additional investments in infrastructure, but the price difference (125,000 USD to 200,000 USD in prices of year 2000) allows us to have substantially shorter investment repayment time.

Despite of some slowness in the hybrid busses commercial application, several companies in the Asia region, mainly in Japan, South Core, and China, are working intensively in this direction as well. 
First hybrid busses were produced in Japan on 1991, by Toyota subsidiary company Hino Motors. The largest producer from China, Shanghai Automotive Industrial Corp. has developed hybrid busses production unit together with General Motors. Another producer from China - FAW, which is the second largest according to the turnover, started production of hybrid busses named Jiefang on 2005, using technology designed by the company Enova from USA. The characteristics of bus - fuel economy $38 \%$, emission decrease by $30 \%$, in comparison with traditional diesel engine driven bus. NiMH accumulators are used as the main energy storage unit in this bus. Company FAW had decided to produce at least 1000 hybrid busses by 2010. Company China Yuchai International Ltd. (China) presented the hybrid bus engine system designed by their engineers and researchers on 2008. The system is based on the parallel hybrid principle with integrated starter - generator.

European producers are rather behind their American and Asian colleagues despites the fact that they started the research of hybrid systems a while ago. United Kingdom is the current leader in the Europe in hybrid systems use, and especially the capital - London, where the municipality decided to purchase only hybrid technologies based new public transportation units starting with 2012 .

All large European transportation means producers like Mercedes, MAN, Scania, VOLVO, are preparing their production facilities for hybrid busses production and commercial production of electric power units of public transportation. Financial support for these activities is being received from their home countries government budgets. MAN in cooperation with Siemens A\&D, using series hybrid drive system with super capacitors as energy storage units, re-designed bus MAN Lion's City production line, but Scania is working on their bus OmniLInk modification using hybrid system designed by company Voith from Austria, and using Maxwell (USA) super capacitors.

DesignLine International Holdings from New Zealand should be mentioned between the serious players in the hybrid buss production segment. First diesel electric hybrid busses were presented by the company already on 1998, and starting with 2000 they introduced Capstone MicroTurbine microturbines, different types of energy storage units including NiMH, LiIon accumulator batteries, and super capacitors, and intellectual power modules SKAI designed by company Semikron. The busses called DesignLineEcoSaver are delivered to USA, United Kingdom, and Japan.

The main hybrid system developers are presented in the Table 3.

Table 3. Leading world hybrid system developers

\begin{tabular}{|l|l|l|}
\hline Series hybrid systems & Parallel hybrid system & Combined hybrid system \\
\hline $\begin{array}{l}\text { BAE Systems (UK). System } \\
\text { HybriDrive }{ }^{\circledR}\end{array}$ & $\begin{array}{l}\text { GM/Allison (USA). System - EP40, EP50 Systems - } \\
\text { EP40, EP50 (mixed parallel system Split modified } \\
\text { for long vehicles) }\end{array}$ & $\begin{array}{l}\text { Enova (USA). Using both } \\
\text { series and parallel hybrid } \\
\text { systems }\end{array}$ \\
\hline $\begin{array}{l}\text { ISE/Siemens (USA). System } \\
\text { Elfa }{ }^{\circledR} \text { (Siemens A\&D, } \\
\text { Germany) }\end{array}$ & $\begin{array}{l}\text { Eaton (USA). System with automatic transmission } \\
\text { Fuller }{ }^{\circledR}\end{array}$ & \\
\hline Voith (Austria). System & & \\
ELVO ${ }^{2}$ & & \\
\hline
\end{tabular}

\subsection{Comparative analysis of energy storage principles}

The latest hybrid bus design includes different energy storage systems - starting with flywheel as mechanical energy storage and recuperation device, and in the electrical energy storage side - from leadacid batteries as the oldest device up to NiMH or LiIon batteries designed especially for transportation units, and electro chemical super capacitors as the latest energy storage modules.

$\mathrm{NiMH}$ andLiIon accumulator batteries are good alternative because of their light weight and high specific power. The main drawbacks are limitations of charging and discharging speed, and substantially shorter lifetime in comparison with super capacitors. Typical lifetime of accumulator batteries is around 6 years, at the same time the lifetime of the bus is more than 10 years. This means that at least two packages of accumulator batteries must be used during the bus application as a public transportation mean. Super capacitor producers are offering their product lifetime longer than $10 \ldots 12$ years, which could mean that there will be no additional expenses for replacement of this type of energy storage devices. 


\section{Electric Energy Transfer Technologies to Moving Objects}

\subsection{Conductive energy transfer}

\subsubsection{Overhead wire grid}

The basic, widely known electric energy transfer principles to the transportation units are based on electric grid and pantograph (moving contact system). This allowed developing specific electricity driven transportation units - trolley busses and trams use this system all over the world.

The main drawbacks are electric grid development and maintenance expenses, fixed lines and fast wear out of the contact systems, which asked for solutions as to wider electric transportation system development.

\subsubsection{Plug-in charging}

Along with electronic components and energy storage development hybrid vehicles and pure electric vehicles appeared. As one of the ideas that is expected to significantly alter electrified transport, the charging station placement throughout the vehicle journey to provide additional accumulator charging. At present there are several competing charging technologies: some of them are already in the testing and implementation phase, while others are still being developed.

The simplest transfer of power from the charging station the vehicle is a direct connection to the vehicle using power cable. Currently, there are several standards for road station to charge the batteries, which uses both DC and AC power.

Positive features of this system are: high system efficiency (more than 99.5\%), the transferred power is limited only by the cable cross-section, the implementation simplicity, absence of electromagnetic interference generation. Weaknesses of the system are: the need for a cable connection, capture and transfer equipment mechanical contact necessity, electrical contact between the reception and transmission equipment necessity, complicate to use during short stops, cannot be used while moving.

Direct connection system is suitable for high capacity accumulator charging, while the vehicle has long stops through the journey, and is not suitable for charging during short time stops.

\subsubsection{Trolley systems}

Trolley system provides electrical contact between the power transmitter and receiver using specific devices - trolleys, located at the stop spot. This system has the following advantages: high efficiency (more than 99.5\%), the possibility of a fast automatic bonding opportunity, absence of electromagnetic interference generation. Weaknesses of the system are: substantial number of mechanical moving part, necessity of capture and transfer equipment mechanical contact, necessity of electrical contact between the reception and transmission equipment, power transmission system contacts pollution impact on system performance, the need to accurately position the vehicle with respect to the charging equipment.

There are different types of trolley system. Company ABB is offering contact plates system positioned on the bus stops [6]. Power receiver is equipped with an automatic positioning system, which allows changing the current location of the receiver relative to the contact plates. ABB Group has also developed a $400 \mathrm{~kW}$ electric buses particularly fast-charging system, which is being tested in Switzerland. The system called TOSA (Trolleybus Optimisation System Alimentation) [7] lets to charge the bus accumulators during the short, just 15 seconds long stop.

Currently, under the pilot project a number of charging stations are installed on the route from Geneva airport, which connects the city to the international exhibition centre. When the bus arrives at the stop, mechanic alarm from the power charger is automatically connected to the bus for charging. While the passengers disembark and are picked up, the battery is charged. At the final destinations it is enough to charge the battery just for 3-4 minutes, and the bus is ready to ride again on the route. Bus length is $19 \mathrm{~m}$, the maximum number of passengers - 135 [8].

Company SIEMENS is offering the trolley system [9], which differs substantially - it allows to charge during the driving. Two parallel positioned power wires and pantograph system, very similar to the one which is being used in current trolley bus system, is being used there. The system is being tested in the pilot project in Vienne, Austria [10]. 


\subsection{Wireless energy transfer}

\subsubsection{Electromagnetic induction system}

The system, which uses electromagnetic induction method, is considered the best prospects direction as it allows transmitting electric energy without direct contact between the receiver and transmitter. The transmission takes place between two adjacent solenoids forming a transformer with linked magnetic field of mutual induction. Alternating current, which flows through the primary winding, is creating a variable magnetic field that creates the alternating electric current in the secondary winding due to induction. The transformer may be with core or coreless, and the transformer primary and secondary winding turns out to be non- electrically connected to each other. Depending on the design of the transformer the energy losses can occur in windings, core, and through the dispersion of electromagnetic field in the environment. Transformer efficiency can reach $98 \%$. Wireless transmission method main disadvantage is its short operating distance. The receiver must be located close to the receiver. With the distance increase the inductive link efficiency decreases substantially.

The resonance transformer principle is being used in order to increase efficiency and the distance between the transmitter and the receiver. Resonance transformer primary winding and secondary winding are having the same oscillating frequencies.

Another way is to increase the efficiency is the non-sinusoidal excitation pulse oscillation circuit use. Energy impulse transmission occurs due to a circuit oscillation cycle. Transmission and perception of the coils is made as single layer solenoids or flat spirals with capacitors, which allows tuning the necessary resonance frequency of the circuit.

The main advantages of this system are as follows: no electrical contact between the electrical power receiver and transmitter, always ready for use, able to use during a short stop, the opportunity to use on moving systems. Weaknesses of the system: short-distance transmission, low efficiency if compared to the contact system, generates high levels of electromagnetic disturbances, design complexity.

\subsubsection{Induction system with joint core}

Classic transformer transmits energy in the form of a variable magnetic field in the magnetic circuit (rod), besides there is no electrical contact between the primary and secondary windings. When establishing a core consisting of two quickly separable parts, one of which is a primary winding, the other secondary, it is possible to increase the no-contact power transmission efficiency by more than $96 \%$. Another advantage of this method worth to mention is small device dimensions. The disadvantage of this method is the need for mechanical contact to join both core parts during charging.

\subsubsection{Resonance induction system}

The system consists of two contours which are tuned to the same frequency. Classically it was suggested to recognize the two circuits as a resonant transformer, however, the contour of the coil can be realized as a beam antenna, but the entire power transmission system - as the interaction between the two antennas, which are located near each other within the radiating area [11]. In this case, the combination of receivers and antennas in the transmitting side can be researched as the phased-array antenna grid. Current stage of research has very limited knowledge about the interaction between the two antennas with very close the radiating area, however, other researchers raised assumptions about the possibility of concentrating energy within the radiating area with a phased-array antenna grid [12]. It is likely that phased-array antenna grid usage could reduce or eliminate the energy dissipation in the surrounding objects and decrease adjacent radiation in the environment, which are the main drawbacks for the traditional induction method [13].

\subsection{Observed transportation line research}

Since the recuperation principle-based hybrid buses are most effective on routes, on which they often have to stop, slow down and change the speed, it is expected that the greatest demand for them, first 
of all, will be at inner-town routes in Riga, in case of Latvia. At the same time, in order to fully appreciate the application of technical and economic parameters of this bus, ideally, pilot route is expected to be partly in-town and partly out-of-town. Another important requirement would be to obtain sufficient electrical connections for extra recharge at bus stops and final stops without significant additional investment.

Recognising those requirements, the most convenient route would be from Riga centre to airport "Riga", allowing to assess bus efficiency on different route stages and generated requirements that could be efficient on various Riga routes, as well as other Latvian cities' and inter-cities' routes.

For similar reasons, many countries select direct routes between major city centres and airports as pilot projects sites (e.g., ABB project in Geneva).

Reviewing the above mentioned route (Abrenes street - „Riga” airport), it is $11.5 \mathrm{~km}$ long, with many stops in city centre and long distances between bus stops outside the city, allowing to precisely assess bus functioning and amount of used electricity during different driving conditions. Infrastructure available at the route final stops and stops complies with pilot project requirements.

Currently, bus total journey time from one final stop to another is 34 minutes, of which 19 minutes are consumed in driving, while 15 minutes are the summary stopping time at the bus stops and parking in the final stop. Depending on what type of wireless charging is chosen, how many stops have extra charging equipment, and how fast is to be the charging process, then these time parameters would remain unchanged or slightly increase. If we compare the above mentioned ABB prototype bus route in Geneva and its flash charging technology, which provides charging at bus stops within 15 seconds, but at the bust final stops within 2 minutes, in case of Riga expected route time could be unchanged.

Feasibility study was carried for the route Airport "Riga" - Riga (current bus route No. 22) to carry out theoretical calculations and to determine the suitability of electric bus and determine if the electric bus could be used for such route and what would be the theoretical limiting requirements for the charging system.

During the feasibility study, it was concluded:

- the total length of the route in one direction is 11,500 meters;

- the total power consumption of the electric bus on the route: $10.72 \mathrm{kWh}$ (calculated from the assumption that specific energy consumption of the bus is $0,93 \mathrm{kWh} / \mathrm{km}$ );

- the total charging time depends on the installed capacity of the charger (not considering the actual characteristics of the battery pack and rechargeable power acceptation capabilities).

The total driving time on the route is 34 minutes, from which:

- the actual driving time: 19 minutes;

- idle time at the stops: 15 minutes.

Thus, in theory, the minimum charger's power requirements are $55.94 \mathrm{~kW}$. Project estimated wireless charging system's amount of power is planned to be $30 \mathrm{~kW}$, therefore the prospective charger configuration is shown in the Table 4.

Table 4. Charger configuration for public transportation line

\begin{tabular}{|l|l|c|l|c|c|}
\hline $\begin{array}{l}\text { Final } \\
\text { destination } \\
\text { point 1 }\end{array}$ & Busstop1...N & $\ldots$ & Busstop X & $\ldots .$. & Final destination point 2 \\
\hline $\begin{array}{l}\text { Super-fast } \\
\text { charging } \\
\text { (conductive) }\end{array}$ & $\begin{array}{l}\text { Quick charging } \\
\text { (inductive) }\end{array}$ & & $\begin{array}{l}\text { Quick charge for the } \\
\text { necessary adjustments along } \\
\text { the route (inductive / } \\
\text { conductive) }\end{array}$ & $\begin{array}{l}\text { Super-fast charging } \\
\text { (conductive) }\end{array}$ \\
\hline $\begin{array}{l}\text { Charging power: } \\
100+\mathrm{kW}\end{array}$ & $\begin{array}{l}\text { Charging power: } \\
30 \mathrm{~kW}\end{array}$ & Charging power: $100+\mathrm{kW}$ & & Charging power: $100+\mathrm{kW}$ \\
\hline
\end{tabular}

Stop $\mathrm{X}$ might require a power adjustment based on the actual bus route, because it is not known at how many bus stops on each route bus actually stops. Additionally, the total charging scheme can be represented by the following linear programming optimization task: 
Minimising $\mathrm{C}$, with the variables $\mathrm{N}$ and $\mathrm{P}$, where

$$
\left\{\begin{array}{c}
\left.P(\text { sum })=P * t(\text { final destination })+\sum_{0}^{N=23} P(N) * t(N) \text { (wireless }\right) \\
C=2 C(\text { final destination })+\sum_{0}^{N=23} C(n)(\text { wireless })+C(\text { bus }) \\
C(\text { each position })=f(P x * X) \\
P(\text { bus })=1.2 y * P(\text { nominal }) \\
N(\text { number of busstops }), 0<N<23 \\
d P(\text { compensation }), 0<d P<P \\
d P=P(\text { busstop } X)+\text { auxiliary } P(\text { bus }) \\
t=f(C)
\end{array}\right.
$$

where

$\mathrm{P}$ - installed charging power, $\mathrm{kW}$;

$\mathrm{C}$ - cost, EUR;

The cost is a function of the power $\mathrm{C}=\mathrm{P}(\mathrm{x}) * \mathrm{X}$, which is not necessarily linear, and must be determined in the research;

$\mathrm{t}$ - charging time dependent on the route and the technology used (expense) (a limiting speed of charge batteries super capacitors, etc.) - a particular function should be determined in the study;

$\mathrm{dP}$ - required compensatory reserve at the stop $\mathrm{X}$, depending on the actual trip, which ranges from 0 (ideally) to $\mathrm{P}$ - in the worst case, if there are no stops between start and final destination, and it is needed to travel the entire route on a single charge;

$\mathrm{y}$ - charge reserve in the accumulator or super capacity, $\%$.

As a concrete solution to the system, in the event of bus stopping at all the stops (thus $\mathrm{dP}=0$ ) is following:

- Number of busstops: 23, charging (wireless) power $30 \mathrm{~kW}$, charging time at the stop is 30 seconds, charge capacity at each stop $=0.25 \mathrm{kWh}$.

- Final stops $=$ charge power of $75 \mathrm{~kW}$, charging time $4 \mathrm{~min}$, charged energy of $4.97 \mathrm{kWh}$.

- Minimum On-board battery capacity: $7 \mathrm{kWh}$, assuming discharge reserve $\mathrm{y}=40 \%$ (battery is charged at $20-80 \%)$.

- Charging speed: 10C (super capacitors are used).

The other extreme charging scenario, in case the bus drives the whole distance without a single stop $(\mathrm{dP}=\mathrm{P})$ :

- Number of bus stops: 0 , wireless charger power $0 \mathrm{~kW}$, charging time in bus stops 0 seconds $=$ charged capacity in each bus stop $=0 \mathrm{kWh}$.

- $\quad$ Final stops = charging power $160 \mathrm{~kW}$, charging time $4 \mathrm{~min}$, charged energy $10.72 \mathrm{kWh}$.

- Minimum On-board battery capacity: $20 \mathrm{kWh}$, assuming discharge reserve $\mathrm{y}=40 \%$. (battery is charged $20-80 \%$ SoC).

- Charging speed: $23 \mathrm{C}$ (super capacitors should be used).

\section{Conclusions}

Initial investigation carried during the reporting period leads to the following conclusions:

- Hybrid transportation systems have a permanent place in the public transportation system, especially in view of fossil fuel prices, and the environmental conditions worsening.

- Serious studies and pilot production of small series hybrid transportation units are taking place worldwide. Recently more and more widespread research of use of hybrid system in the public transport states the economical and environmentally friendly viability of electricity driven city transportation systems.

- Rather limited research results are available about the hybrid busses using super capacitors, and about the automatic control principles and electrical wiring principles of combined systems including electric motors, diesel-generator systems, accumulator batteries and super capacitors. 
- Research data about medium power (above $20 \mathrm{~kW}$ ) wireless energy transfer systems and their application for transportation units energy supply are unavailable. Also the technical requirements of such systems are not developed yet.

- The main activities of hybrid vehicles developers are oriented on the vehicle technical development, very limited interest devoted to power supply system. The power grid specialists are not acquainted with the impulse wireless energy transfer, because of no demand for these systems.

\section{Acknowledgements}

The activity of "LEO Pêtījumu Centrs" and this paper on the research project "The possibilities of increasing efficiency of city bus hybrid propulsion systems by including wireless battery charging" is carried out within grant program by European Regional Development Fund for general industrial research and for projects dealing with new product and technology developments. Latvian Investment and development agency Contract number: L-KC-11-0006 project number: KC/2.1.2.1.1/ 10/01/005

\section{References}

1. EU COM (2011) 144 Roadmap to a Single European Transport Area, sect.2.5. (1), from http://eurlex.europa.eu/LexUriServ/LexUriServ.do?uri=COM:2011:0144:FIN:en:PDF

2. Pierre Ducharme, Simon Ouellette. (2013) Transit fleet optimization planning. In Proceedings of EVS27 International Battery, Hybrid and Fuel Cell Electric Vehicle Symposium, 2013.

3. http://www.matternetwork.com/2009/2/energy-efficient-transit.cfm

4. US DoT Federal Transit Administration. (2007) Useful Life of Transit Buses and Vans. Report nr.FTA VA-26-7229-07.1.

5. Xiaogang Wu1, Jiuyu Du, Chen Hu, Tingting Jiang. (2013) The Influence Factor Analysis of Energy Consumption on All Electric Range of Electric City Bus in China. In Proceedings of EVS27 International Battery, Hybrid and Fuel Cell Electric Vehicle Symposium, 2013.

6. http://www.thisisnottingham.co.uk/Fleet-electric-buses-creates-buzz-city/story-16837941detail/story.html

7. http://www.bbc.co.uk/news/uk-england-coventry-warwickshire-18420557

8. http://www.bbc.co.uk/news/uk-england-beds-bucks-herts-19714571

9. http://phys.org/news/2011-04-arctic-fast-charging-hybrid-electric.html

10. www.byd.com/auto/ElectricBus.html

11. International Energy Agency. Agreement of Hybrid and Electric Vehicles Executive Committee Meeting, 16.10.2013, Stuttgart.

12. Technical data of hybrid bus CITEA

13. http://www.electric-vehiclenews.com/2013/05/abb-unveils-wireless-electric-bus-with.html

14. http://www.greentechmedia.com/articles/read/Siemens-Plans-to-Clean-Up-Trucking-with-a-TrolleyLine

15. http://djvan.ru/news/korejskie-zheleznye-dorogi-proveli-ispytaniya-besprovodnoj-peredachielektroenergii/

16. http://www.electric-vehiclenews.com/2013/05/abb-unveils-wireless-electric-bus-with.html

17. http://www.tosa2013.com/\#/tosa2013

18. http://www.abb.com/cawp/seitp202/f32c9ded54dc0b20c1257b7a0054972b.aspx

19. http://www.greentechmedia.com/articles/read/Siemens-Plans-to-Clean-Up-Trucking-with-a-TrolleyLine

20. http://www.siemens.com/press/pool/de/events/2013/infrastructure-cities/2013-03-UITP-PK/backgroundebus-wiener-linien-e.pdf

21. Vendik, O. G., Pakhomov, I. A. (2005) Electric- and Magnetic-Field Strength in the Frensel Zone of a Microradiator Formed by an Electric and a Magnetic Dipole. Journal of Technical Physics, 75(11). (In Russian)

22. Smirnov, V. Yu., Nikitin, O.R. (2008) Linear Phased Antenna Arrays Focused in Near Zone. Vestnik RGRTU, 4(26) Ryazan, 2008. ISSN 1995-4565. (In Russian) 
23. Xiaofang Yu, Sunil Sandhu, Sven Beiker, Richard Sassoon \& Shanhui Fan. (2011) Wireless energy transfer with the presence of metallic planes. APPLIED PHYSICS LETTERS, 99, 214102

24. Chun Qiu, K. T. Chau, Chunhua Liu \& C. C. Chan. (2013) Overview of Wireless Power Transfer for Electric Vehicle Charging. In Proceedings of EVS27 International Battery, Hybrid and Fuel Cell Electric Vehicle Symposium, 2013.

25. Covic, G. A. \& J. T. (June 2013) Boys. Inductive power transfer. In Proc. IEEE, vol. 101, pp. 1276-1289. 